\title{
A window into fungal endophytism in Salicornia europaea: deciphering fungal characteristics as plant growth promoting agents
}

\author{
Bliss Ursula Furtado • Sonia Szymańska • \\ Katarzyna Hrynkiewicz
}

Received: 18 February 2019 /Accepted: 24 September 2019 /Published online: 30 October 2019

(C) The Author(s) 2019

\begin{abstract}
Aim Plant-endophytic associations exist only when equilibrium is maintained between both partners. This study analyses the properties of endophytic fungi inhabiting a halophyte growing in high soil salinity and tests whether these fungi are beneficial or detrimental when non-host plants are inoculated.

Method Fungi were isolated from Salicornia europaea collected from two sites differing in salinization history (anthropogenic and naturally saline) and analyzed for plant growth promoting abilities and non-host plant interactions. Results Most isolated fungi belonged to Ascomycota (96\%) including dematiaceous fungi and commonly known plant pathogens and saprobes. The strains were metabolically active for siderophores, polyamines and indole-3-acetic acid (mainly Aureobasidium sp.) with very low activity for phosphatases. Many showed proteolytic, lipolytic, chitinolytic, cellulolytic and amylolytic
\end{abstract}

Responsible Editor: Ian Dodd.

Electronic supplementary material The online version of this article (https://doi.org/10.1007/s11104-019-04315-3) contains supplementary material, which is available to authorized users.

B. U. Furtado · S. Szymańska · K. Hrynkiewicz Department of Microbiology, Faculty of Biology and Environmental Protection, Nicolaus Copernicus University, Lwowska 1, 89-100 Torun, Poland

B. U. Furtado • S. Szymańska • K. Hrynkiewicz $(\bowtie)$ Interdisciplinary Center of Modern Technologies, Nicolaus Copernicus University, Wileńska 4, 87-100 Torun, Poland e-mail: hrynk@umk.pl activities but low pectolytic activity. Different activities between similar fungal species found in both sites were particularly seen for Epiccocum sp., Arthrinium sp. and Trichoderma sp. Inoculating the non-host Lolium perenne with selected fungi increased plant growth, mainly in the symbiont (Epichloë)-free variety. Arthrinium gamsii CR1-9 and Stereum gausapatum ISK3-11 were most effective for plant growth promotion. Conclusions This research suggests that host lifestyle and soil characteristics have a strong effect on endophytic fungi, and environmental stress could disturb the plant-fungi relations. In favourable conditions, these fungi may be effective in facilitating crop production in non-cultivable saline lands.

Keywords Salinity · Halophyte · Grass · Endophyte · Fungi $\cdot$ Plant growth promotion

\section{Introduction}

Endophytic fungi are the functionally vital members of the plant microbiome colonising varied plant species (Porras-Alfaro and Bayman 2011; U'Ren et al. 2012) causing no visible damage or disease symptoms in their host (Rodriguez et al. 2008). Abiotic factors, e.g. seasonal fluctuations and changes in soil chemical properties disturb the microbiological balance, eventually favouring the survival and increase of the more robust and competitive microbes, which commonly include the fungal pathogens or saprophytes (Pritchard 2011). 
Although some endophytes evolve from plant pathogenic fungi and may cause disease of plants under stress conditions (Redman et al. 2005), the true endophyte state (non-pathogenic) is established during their longterm association in the host plant.

Fungal enzymes play an important role in the mineralisation and degradation of organic materials and these enzymes may affect other microorganisms, by competing for plant host entry and nutrients inside the plant. Most plants contain secondary metabolites that protect them from pathogens, and some metabolites probably affect the entry of endophytic fungi (Jia et al. 2016). The fungi secrete detoxification enzymes, such as cellulases, lipase, xylanase, and protease, which can decompose these secondary metabolites before they penetrate the defence systems of their host (Sieber 2007). The plant - endophytic microbial interaction only exists when equilibrium is achieved between the colonising fungi and the chemical reactions of the host plant and maintained over time (Kogel et al. 2006).

Once the endophytic niche is established, the fungi may benefit and enhance plant fitness. Plants inhabited by fungal endophytes show increased vegetative vigour (Groppe et al. 1999); higher production of generative tillers (Clay 1990); better defences against invasive fungi (Arnold et al. 2003) and various phytopathogens (Arnold et al. 2003; Mendoza and Sikora 2009); deterrence against herbivores (Herre et al. 2007), insects (Wilkinson et al. 2000) and nematodes (Kimmons et al. 1990); and abiotic stress tolerance (Redman et al. 2002; Rodriguez et al. 2004). The endophytic fungi may produce vital bioactive metabolites and secondary compounds, exclusive of those produced by their host plants that may contribute to plant fitness and that can stimulate the production of novel metabolites for pharmaceutical use (Zhang et al. 2006). In return, the residing endophytes gain a specific ecological niche, access to nutrients, protection from abiotic stress and desiccation, and dissemination to the next generation of hosts (vertical transmission via seeds) (Faeth and Fagan 2002).

The functional role of endophytic fungi may be determined by the type of environment they are adapted to. For instance, endophytic fungi isolated from plants in geothermal soils demonstrate thermotolerance (Rodriguez et al. 2004), those from heavy metal contaminated areas revealed significant mechanisms of metal tolerance (An et al. 2015) and strains obtained from medicinal plants produced bioactive compounds (Ganley et al. 2004). Endophytic fungi isolated from the halophyte Suaeda salsa conferred salt stress tolerance in rice seedlings (Qin et al. 2017). Thus it is clear that the traits of endophytic fungi are imposed by the type and conditions of their host plant (e.g. Arnold et al. 2003; Redman et al. 2002; Waller et al. 2005).

Despite extensive work on fungal endophytehalophyte systems (e.g. Bilal et al. 2018; Gopi and Jayaprakashvel 2017; Indira et al. 2015; Khalmuratova et al. 2015; Maciá-Vicente et al. 2012; Sun et al. 2011a, b), there is limited information on the properties of endophytic fungi from saline habitats and how they contribute to improving the plant performance. Consequently, in this study we investigated a salt-accumulating halophyte, Salicornia europaea L. (family Amaranthaceae), which is one of the most salt tolerant halophytes in the world (Nikalje et al. 2017). This halophyte can develop in very high salinity conditions ( $1 \mathrm{M} \mathrm{NaCl}$ in soil) (Ushakova et al. 2005). S. europaea is extensively established in the two saline sites selected in this study. It is generally identified to comprise varied physiological and biological adaptive mechanisms, which allow it to survive under extreme saline conditions (Nikalje et al. 2017). Since Salicornia endophytes establish and stabilise in their host tissues, it is interesting to speculate whether these fungi inherit traits related to alleviating salt stress conditions (e.g. different source of salinity present at two test sites: anthropogenic and natural) or whether they produce some beneficial compounds. Endophytic bacterial strains isolated from other halophytes show plant growth promoting capabilities when Salicornia brachiata (Jha et al. 2012), S. europaea (Zhao et al. 2016), Limonium sinense (Qin et al. 2014), Beta vulgaris (Piernik et al. 2017), Cucumis sativus and Oryza sativa (Yuan et al. 2016) were inoculated. Similarly, some studies on the plant growth promoting traits of endophytic fungi isolated from halophytes were observed in Carex kobomugi (Hwang et al. 2011), Waito rice seedlings (Young-Hyun et al. 2012) and Chinese white poplar (Pan et al. 2018). To our knowledge, this is the first report on the potential role of endophytic fungi from S. europaea.

In our previous report, we performed metagenomic analysis to reveal the Salicornia endophytic bacterial and fungal community in the same selected saline sites in two seasons (Furtado et al. 2019). Hence, in this study we aim to reveal the culturable endophytic fungal diversity as a consequence of differing soil salinity at the two sites and the potential activity of endophytic fungi in promoting non-host plant growth. We selected the perennial ryegrass Lolium perenne as a non-host model plant as it is particularly popular for its high-quality turf and valuable forage (Wilkins 1991). This grass is 
associated with Epichloë sp. (known as Neotyphodium sp.) which is a symbiont of cool-season grasses of the family Pooideae that is vertically transmitted through seeds (Leuchtmann et al. 2014). Species of Epichloë are known to produce bioactive alkaloids that protect the grasses from herbivores and insect damage (Saikkonen et al. 2016). We hypothesised that: (i) fungal endophytes of the obligatory halophyte $S$. europaea consist of a unique group of isolates with plant growth promoting metabolic activity and tolerance to high salt concentrations, analogous to their host, (ii) the resilience and compatibility of fungal endophytes can be tested by inoculating them in non-host plants, which can prove to be a beneficial association.

\section{Materials and methods}

Sample collection and isolation of endophytic fungi

The plant samples of $S$. europaea were collected from two saline sites. The two saline sites are located in the Kujawy region in Central Poland: site 1 (S1) is situated in the vicinity of three brine graduation towers in the Spa Park in Ciechocinek (natural source of salinity) and site 2 (S2) is a meadow next to the waste ponds of a soda factory in Inowroclaw (anthropogenic source of salinity). The characteristics of the soils at the two sites are previously described in Furtado et al. 2019. S1 sometimes has significantly higher salinity than S2, with the electrical conductivity $\left(\mathrm{EC}_{\mathrm{e}}\right)$ of soil samples collected in autumn 2015 being 100.5 and $76.0 \mathrm{dS} \mathrm{m}^{-1}$ respectively. However, the $\mathrm{EC}_{\mathrm{e}}$ of the soil samples collected in the spring 2016 were quite similar at 51.1 and $59.7 \mathrm{dS} \mathrm{m}^{-1}$ respectively. Soil samples from S1 had significantly higher $\mathrm{Na}^{+}$levels, while S2 had significantly higher $\mathrm{Ca}^{2+}$ levels in both sampling seasons (Furtado et al. 2019).

The plant samples (each sample consisting of at least 10 plants) were collected from three plots in each of the saline sites during the two seasons (autumn 2015 and spring 2016). Samples from each plot were collected in triplicate (36 samples in total). The plants were thoroughly washed in sterile distilled water to remove adhering soil followed by the surface sterilization technique described by Hrynkiewicz et al. (2010) with modifications. The shoots and roots were separately washed in sterile $2 \% \mathrm{NaCl}(6$ times), and subsequently using sterile hydrogen peroxide $\left(\mathrm{H}_{2} \mathrm{O}_{2}\right)$ solution for $5 \min \left(2 \% \mathrm{H}_{2} \mathrm{O}_{2}\right.$ for shoots and $5 \%$
$\mathrm{H}_{2} \mathrm{O}_{2}$ for roots). The plant samples were finally rinsed with sterile $2 \% \mathrm{NaCl}$ (3 times) and the last solution was plated to check for optimization of sterilization technique. The shoots and roots were dried using sterile filter paper and ground to a fine paste in a mortar. A series of serial dilutions were performed. Using the pour plate technique $1 \mathrm{ml}$ suspension was mixed with potato dextrose agar (PDA) (Difco, BD Biosciences) supplemented with tetracyclin $(30 \mu \mathrm{g} / \mathrm{ml})$. To increase the probability of obtaining most of the culturable endophytic fungi, PDA was amended with different salt concentrations $(0 \mathrm{mM}$, $100 \mathrm{mM}$, and $200 \mathrm{mM} \mathrm{NaCl}$ ). All the dilutions and plating were prepared in three replicates. The plates were incubated at $24 \pm 2{ }^{\circ} \mathrm{C}$ and observed regularly for fungal growth and isolates were selected (selection based on the colony morphological features such as colour, margin, mycelium form and microscopic slide preparations as described in Germain and Summerbell (2010) and transferred to fresh PDA plates during this period.

Molecular identification of endophytic fungi

DNA isolation for 320 endophytic fungi was performed using GeneMATRIX environmental DNA extraction kit (EurX, Poland) following the manufacturer's protocol. Universal primers ITS1 (5-CTTGGTCATTTAGA GGAAGTAA-3) and ITS4 (5-TCCTCCGCTTATTG ATATGC-3) (Manter and Vivanco 2007) were used to amplify the internal transcribed sequence (ITS) region using thermal cycler (Qiagen). Amplification products were resolved by agarose gel electrophoresis $(1 \%)$ and visualized using a gel documentation system (UVP, MultiDoc-It ${ }^{\mathrm{TM}}$ System). The PCR products were purified using the PCR purification kit (GenoPlast Biochemicals), quantified at $260 \mathrm{~nm}$ using Nanodrop (Thermo Scientific ${ }^{\mathrm{TM}}$ NanoDrop 2000) and confirmed on agarose gel electrophoresis $(1 \%)$. The samples were commercially sequenced in the sequencing facility of the Institute of Biochemistry and Biophysics Polish Academy of Sciences (IBB, Warsaw, Poland). The sequences were analyzed using the Sequencher version 5.1 and were compared with available sequences from the NCBI database. The sequences showing 99\% similarity were retrieved by Nucleotide Basic Local Alignment Search Tool (BLASTn) program available at the National Center for Biotechnology Information (NCBI) BLAST server (www.ncbi.nlm.nih.gov/BLAST). Evolutionary analyses were conducted in MEGA 7 (Tamura et al. 2013). 
Plant growth promoting (PGP) traits of endophytic fungi

Thirty-nine endophytic fungal strains (Fig. 3) were selected from a collection of 320 fungal isolates. Selection criteria were based on information provided in the literature search for all strains, selecting only nonpathogenic strains for further screening. The fungal strains were cultivated on PDA agar at $24 \pm 2{ }^{\circ} \mathrm{C}$ and the 7-day old mycelium was used as inoculum for screening all activities. All the tests were conducted in triplicate. Positive and negative controls using bacterial strains were also maintained for all experiments (strains previously reported by Szymańska et al. (2016) and strain collection retrieved from the Department of Microbiology, Nicolaus Copernicus University, Poland).

\section{Synthesis of siderophores}

Secretion of siderophores by the strains was determined according to the modified method of Alexander and Zuberer 1991 using Chrome azurol S (CAS) agar media. The strains were inoculated on CAS agar and incubated at $26 \pm 2{ }^{\circ} \mathrm{C}$ for 7 days.

\section{Phosphate solubilizing capacity}

The efficiency of strains to solubilize organic phosphates was determined according to Pikovskaya (1948). The strains were inoculated on the Pikovskaya agar containing two different sources of phosphates. One set contained Pikovskaya agar with tricalcium phosphate (TCP) while the other set contained Pikovskaya agar with dicalcium phosphate (DCP). The plates were incubated at $24 \pm 2{ }^{\circ} \mathrm{C}$ for 7 days.

\section{Indole-3-acetic-acid (IAA) synthesis}

The ability of endophytic fungi to produce IAA was assessed based on the colorimetric methods described by Bose et al. (2013) and Gordon and Weber (1951) with slight modifications. Fungal strains from PDA plates were inoculated in $100 \mathrm{ml}$ of Malt Extract medium (Difco) supplemented with $500 \mu \mathrm{g} / \mathrm{ml} \mathrm{L-}$ tryptophan and incubated at $24 \pm 2{ }^{\circ} \mathrm{C}$ on a shaker at $120 \mathrm{rpm}$ for 7 days. The fermented broth was centrifuged at $8000 \mathrm{rpm}$ for $15 \mathrm{mins}$ to separate mycelium growth. The above supernatant $(2 \mathrm{ml})$ was used to estimate the amount of IAA produced by the fungal strains.

\section{Polyamine production}

Polyamine production was detected by inoculating strains on Long Ashton Decarboxylase (LAD) agar (protocol according to Amprayn et al. 2012) and $\mathrm{pH}$ was adjusted to 5.5 (Cloete et al. 2009). Inoculated LAD agar plates were incubated in the dark at $24 \pm 2{ }^{\circ} \mathrm{C}$ for 7 days. Red halos on a yellow background indicated arginine decarboxylation by the strain.

Enzyme production by endophytic fungi

Enzyme assays for the selected 39 endophytic fungal strains were assessed for the following activities: proteolytic activity for hydrolysis of gelatin (Smibert and Krieg 1994), cellulolytic activity for hydrolysis of carboxymethylcellulose (CMC) (Berg and Pettersson 1977), pectinolytic activity for pectin hydrolysis (Strzelczyk and Szpotański 1989), chitinolytic activity for chitin hydrolysis (Agrawal and Kotasthane 2012), amylolytic activity for starch hydrolysis and lipolytic activity for hydrolysis of tributyrin (Gibson and Gordon 1974). The endophytic fungal strains were cultivated in fresh Potato dextrose agar (PDA) plates and used for the analysis of different enzyme activities. The test plates were incubated at $24 \pm 2{ }^{\circ} \mathrm{C}$. The plates were stained after 8 days and the presence of a halo zone or zone of clearance around the fungal mycelia confirmed the positive enzyme activity. Positive and negative bacterial strains for all the activities were used as controls (these strains previously reported by Szymańska et al. (2016) and strain collection retrieved from the Department of Microbiology, Nicolaus Copernicus University, Poland).

\section{Salt tolerance tests}

The salt tolerance of endophytic fungal strains was evaluated on different concentrations of $\mathrm{NaCl}$. The test was performed by transferring 7-day old fungal mycelium plugs onto PDA agar plates supplemented with $0 \mathrm{mM}, 200 \mathrm{mM}, 500 \mathrm{mM}$ and $700 \mathrm{mM} \mathrm{NaCl}$ concentrations. All tests were performed in triplicate. The plates were incubated at $24 \pm 2{ }^{\circ} \mathrm{C}$ and the diameter of the mycelium was measured at 2, 5 and 7 days during the incubation period. 
Plant growth promotion experiment

We selected Lolium perenne as a model plant in this study, to test the effects and endophytes' capability in promoting plant growth. The seeds of the two ryegrass (L. perenne) varieties: variety 1 (Epichloë free: $\mathrm{E}^{-}$) and variety 2 (Epichloë infected: $\mathrm{E}^{+}$) were provided by DLF Seeds A/S, Denmark. The two varieties were sown in trays $(54$ pots of $6 \times 6 \mathrm{~cm})$ filled with sterile sand: vermiculite (1:1). The plants were grown in a sterile growth chamber at $\sim 22-24{ }^{\circ} \mathrm{C}$ and a $16 \mathrm{~h}$ light period under a sodium lighting system. Simultaneously, the six endophytic fungal strains were selected (based on their metabolic activity: positive for IAA, siderophores, polyamines and enzyme activity: positive for cellulase, protease). These strains were cultivated in malt extract medium (Difco, BD) for 7 days, then the fungal mycelium was collected and washed in sterile distilled water and crushed using sterile glass beads to obtain dispersed inoculum. This fungal mycelium $(500 \mu \mathrm{l})$ was inoculated at the shoot-root junction of the 1 week old germinated ryegrass seedlings and maintained under controlled conditions. The plants were watered using sterile distilled water twice a week and Hoagland's medium was added once a week during the 7 week incubation period. The non-inoculated plants of the two varieties served as controls and 27 plant replicates were maintained for all treatments. Twelve plants were randomly selected from each treatment and the remaining plants were stored for further analysis. Observations on the shoot and root length, wet and dry weight of roots and shoots were evaluated.

\section{Data analysis}

The coefficient of activity $\left(\mathrm{W}_{\mathrm{act}}\right)$ was calculated using the formula proposed by Hrynkiewicz et al. 2010: where $\mathrm{S}_{\mathrm{h}}$ indicates the diameter of the hydrolysis zone, $\mathrm{S}_{\mathrm{c}}$ indicates the colony diameter and $t$ indicates the time of incubation, $\mathrm{W}_{\mathrm{act}}=\mathrm{S}_{\mathrm{h}}{ }^{2} /\left(\mathrm{S}_{\mathrm{c}} \times \mathrm{t}\right)$. Statistical analysis for the data showing the effect of fungal inoculation on plant growth was conducted using Statistica software package (version 10.0, StatSoft 2006). Evolutionary analyses were conducted in MEGA X (Kumar et al. 2008). Reference sequences (100 sequences) were obtained from the NCBI blast search. The evolutionary history was inferred using the Neighbor-Joining method (Saitou and Nei 1987). The percentage of replicate trees in which the associated taxa clustered together in the bootstrap test (1000 replicates) is depicted next to the branches (Felsenstein 1985). The evolutionary distances were computed using the p-distance method (Nei and Kumar 2000) and are in the units of the number of base differences per site. The phylogenetic tree was redesigned using Interactive tree of life (iTOL) v3 (Letunic and Bork 2016).

\section{Results}

Taxonomic classification of endophytic fungal strains of $S$. europaea

In total, 320 endophytic fungal strains were isolated from the roots and shoots of $S$. europaea collected from the two salt-affected sites during the two seasons. All DNA sequences obtained were submitted to GenBank SUB5097742 and accession numbers were assigned: MK460774 - MK461093 (see Table 1. Supporting information). We obtained 165 endophytic fungal strains ( 85 in autumn and 80 in spring) from S1 (natural source of salinity) and 155 endophytic fungal strains (72 in autumn and 83 in spring) from S2 (anthropogenic source of salinity). The growth rate of many isolated fungal strains revealed strong effects of salinity based on the analysis in PDA media, which decreased in the following order $0 \mathrm{mM}>100 \mathrm{mM}>200 \mathrm{mM} \mathrm{NaCl}$ salt concentrations. The collection of identified endophytic fungal strains from $S$. europaea mainly consisted of the phylum Ascomycota (96\%) (Fig. 1). The strains were represented by nine orders: Pleosporales (representing $67.9 \%$ dominated by the genera Alternaria sp. and Stemphylium sp.), Eurotiales (representing 16.1\%, and mainly including the genera Aspergillus sp. and Penicillium sp.), and Hypocreales (representing 5.7\% and consisting of only Fusarium sp. and Trichoderma sp.). The remaining genera represented the order Dothideales, Incertae sedis, Capnodiales, Sordariales, Botryosphaeriales and Chaetothyriales.

Most of the endophytic fungal strains represented the order Pleosporales and were found in all sites, seasons and plant organs. Among the strains classified to Ascomycota, Alternaria sp. (67.9\%) was the most dominant genus found in both investigated sites (Fig. 2). Alternaria species were more prevalent at S2. Other species belonging to Aspergillus, Stemphylium and Phoma were found frequently at both sites. 
Some fungal strains belonged to the Phylum. Basidiomycota (4\%) (Fig. 1), which was categorised into four orders, Polyporales (45.4\% with the most representative genus being Peniophora) and the other strains corresponded to Russulales, Agaricales and Cantharellales.

\section{Selection of non-pathogenic strains}

On the basis of information available in previously published articles, we selected 39 fungal strains (Fig. 3 ). As described in Fig. 3 the strains belonged to the genera: Aureobasidium (6 strains), Coprinellus (2), Epiccocum (6), Stereum (1), Podospora (1), Coriolopsis (1), Trichoderma (5), Arthrinium (6), Acremonium (1),
Porostereum (1), Stemphylium (1), Emericellopsis (2), Neocamarosporium (1), Ascochyta (2), Sarocladium (2), and Ascomycota (1). These strains were used to screen for the plant growth promoting activities of fungi.

Plant growth promoting characteristics of the 39 endophytic fungal strains

The results presented in Fig. 3 (see Table 2. Supporting information provides detailed numerical values) showed that most of the endophytic fungal strains from both the $\mathrm{S} 1$ and $\mathrm{S} 2$ produced siderophores, polyamines, and IAA but showed very low or no activity for DCP, and TCP solubilization. Nearly all of the fungal strains from S2 possessed the ability to produce polyamines $(90 \%$

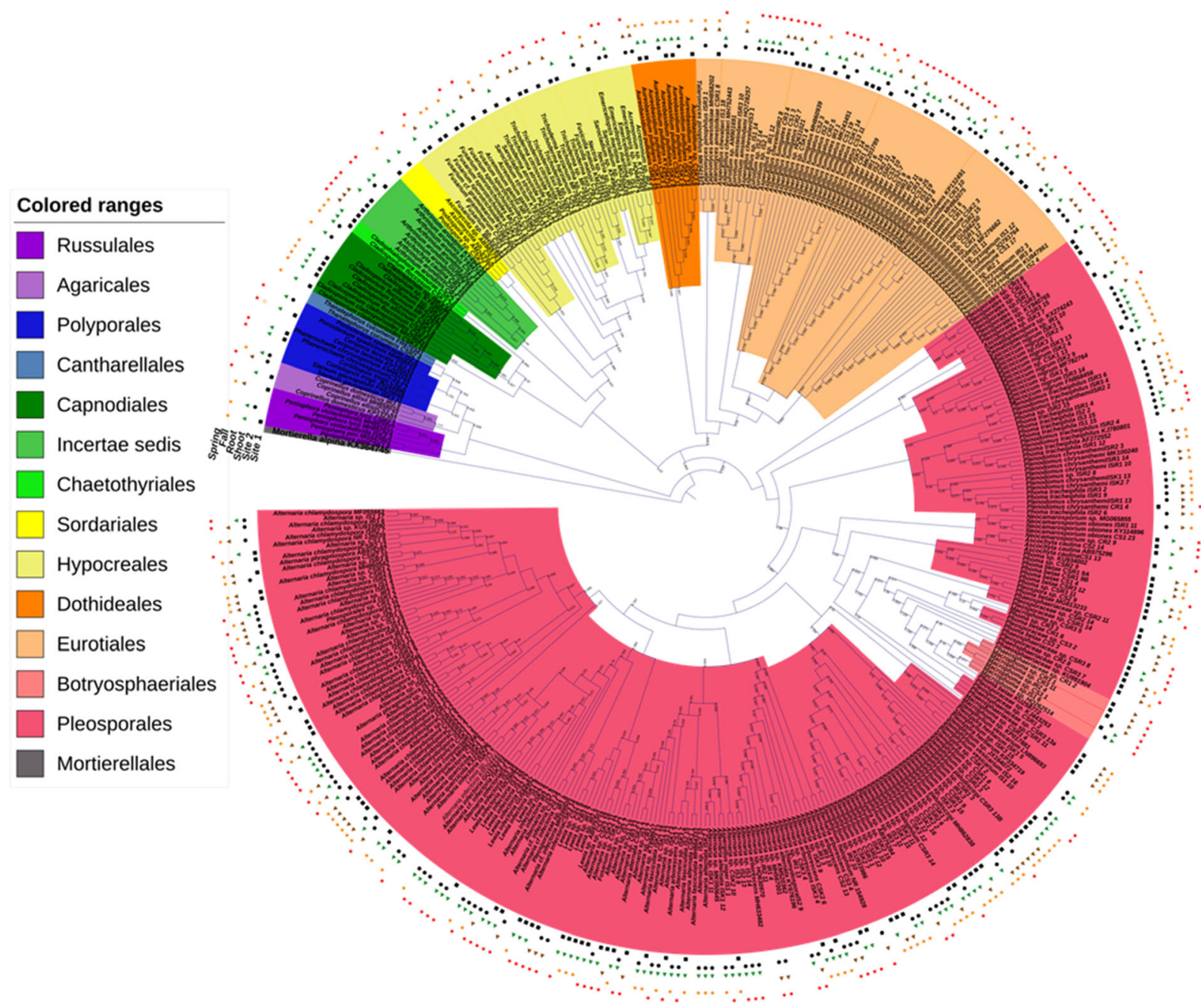

Fig. 1 Phylogenetic analysis of culturable endophytic fungi isolated from $S$. europaea classified in order level. The optimal tree with the sum of branch length $=5.408$ is shown. For details of isolates with their Genbank accession no. see supporting information Table 1 
isolated strains from shoots and $83 \%$ from roots) and siderophores $\left(\mathrm{W}_{\text {act }}\right.$ value ranging from 1 to $10 ; 70 \%$ from shoots and $83 \%$ from roots) compared to the strains from S1. Ascomycota sp. ISK3-7, Arthrinium arundinis IS3-2, A. arundinis CS2-15, Coprinellus ellisii CS1-21, and A. arundinis CS1-14 were only positive for polyamine production. Similarly, Trichoderma sp. CR3-5, Trichoderma harzianum CR2-3, Stemphylium sp. IS3-12 and Aureobasidium pullulans ISR2-10 were only active for IAA synthesis. The ability to biosynthesise IAA was detected at similar frequencies $\left(\mathrm{W}_{\text {act }}<1\right)$ in fungi isolated from sites $\mathrm{S} 1$ and S2. However, most strains located in the plant roots synthesised IAA (87\% from S1 and $83 \%$ from S2), whereas polyamine producers (66\% from S1 and $90 \%$ from S2) were found mainly in the shoots. The strains
A. pullulans CSK1-9, A. pullulans CSK3-1, Aureobasidium sp. CSK3-6 and Emericellopsis maritima IR3-5 were active producers of siderophores $\left(\mathrm{W}_{\text {act }}>1\right)$, polyamine, DCP $\left(\mathrm{W}_{\text {act }}=0.5\right)$ and IAA synthesis.

Extracellular enzymatic activities of the 39 endophytic fungal strains

Most of the endophytic fungal strains isolated from both S1 and S2 displayed proteolytic, lipolytic and chitinolytic activity (Fig. 3). On comparing the two sites, the fungal strains from $\mathrm{S} 1$ possessed higher cellulolytic $\left(\mathrm{W}_{\text {act }}\right.$ ranging from 1 to $<25,66 \%$ isolated strains from shoot and $50 \%$ from roots), proteolytic ( $100 \%$ isolated strains from both organs)

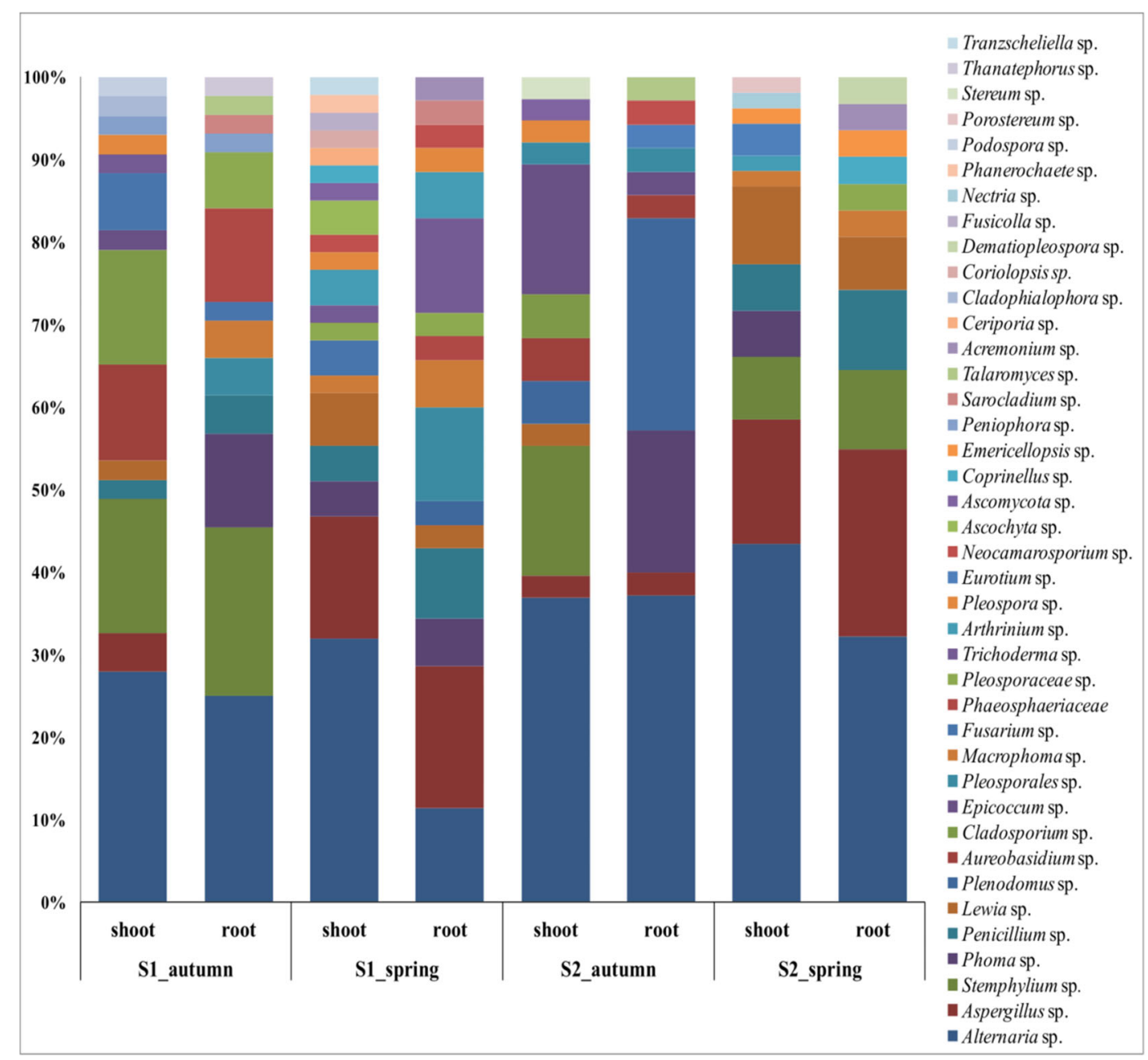

Fig. 2 Percentage occurrence of culturable endophytic fungal species belonging to 40 genera associated with $S$. europaea shoots
(S) and roots (R) during two seasons (autumn \& spring) from two salt-affected sites (S1 \& S2) 


\begin{tabular}{|c|c|c|c|c|c|c|c|c|c|c|c|c|c|c|c|c|}
\hline $\begin{array}{c}\text { Sampling } \\
\text { Area }\end{array}$ & Season & $\begin{array}{l}\text { Plant } \\
\text { tissue }\end{array}$ & $\begin{array}{c}\text { Genbank } \\
\text { accession no. }\end{array}$ & Strain name & Phylum & 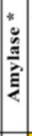 & " & 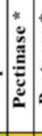 & & 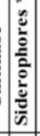 & 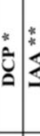 & & 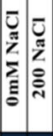 & 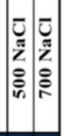 & & \\
\hline \multirow{23}{*}{ Site 1} & \multirow{7}{*}{ Autumn } & \multirow{15}{*}{ Shoot } & MK460869 & Arthrinium arundinis_CS1-14 & A & & & & & & & & & & & \\
\hline & & & MK460887 & Arthrinium arundinis_CS2-15 & A & & & & & & & & & & & \\
\hline & & & MK460886 & Aschochyta caulina_CS2-14 & A & & & & & & & & & & & \\
\hline & & & MK460868 & Ascochyta caulina_CS1-13 & A & & & & & & & & & & & \\
\hline & & & MK460783 & Aureobasidium pullulans_CSK1-11 & A & & & & & & & & & & & \\
\hline & & & MK460781 & Aureobasidium pullulans_CSK1-9 & A & & & & & & & & & & & \\
\hline & & & MK460801 & Aureobasidium pullulans_CSK3-I & $\mathrm{A}$ & & & & & & & & & & & \\
\hline & \multirow{8}{*}{ Spring } & & MK460805 & Aureobasidium sp._CSK3-6 & $\mathrm{A}$ & & & & & & & & & & & \\
\hline & & & MK460874 & Coprinellus ellisii_CS1-21 & B & & & & & & & & & & & \\
\hline & & & MK460879 & Coriolopsis trogii_CS2-2 & B & & & & & & & & & & & \\
\hline & & & MK460785 & Epicoccum sp._CSKI-13 & $\mathrm{A}$ & & & & & & & & & & & \\
\hline & & & MK460876 & Neocamarosporium obiones_CS1-23 & $\mathrm{A}$ & & & & & & & & & & \multirow{14}{*}{$\begin{array}{c}\text { No activity } \\
\text { positive } \\
0.5 \\
1 \\
5 \\
10 \\
15 \\
20 \\
25 \text {--above }\end{array}$} & LEGEND \\
\hline & & & MK460799 & Podospora sp._CSK2-13 & A & & & & & & & & & & & \\
\hline & & & MK460811 & Trichoderma atroviride_CSK3-13 & $\mathrm{A}$ & & & & & & & & & & & Fungal colony \\
\hline & & & MK460881 & Trichoderma sp._CS2-6 & $\mathrm{A}$ & & & & & & & & & & & diameter in $\mathrm{cm}$ \\
\hline & Autumn & \multirow{8}{*}{ Root } & MK460909 & Arthrinium arundinis_CR1-10 & $\mathrm{A}$ & & & & & & & & & & & \\
\hline & \multirow{7}{*}{ Spring } & & MK460915 & Arthrinium arundinis_CR2-4 & $\mathrm{A}$ & & & & & & & & & & & \\
\hline & & & MK460908 & Arthrinium gamsii_CRI-9 & $\mathrm{A}$ & & & & & & & & & & & 2 \\
\hline & & & MK460924 & Sarocladium sp._CR3-2 & $\mathrm{A}$ & & & & & & & & & & & 4 \\
\hline & & & MK460825 & Sarocladium strictum_CSR1-13 & $\mathrm{A}$ & & & & & & & & & & & 6 \\
\hline & & & MK460901 & Trichoderma citrinoviride_CR I-1 & $\mathrm{A}$ & & & & & & & & & & & \\
\hline & & & MK460914 & Trichoderma harzianum_CR2-3 & $\mathrm{A}$ & & & & & & & & & & & 8 \\
\hline & & & MK460927 & Trichoderma sp._CR3-5 & $\mathrm{A}$ & & & & & & & & & & & 10 \\
\hline \multirow{17}{*}{ Site 2} & \multirow{7}{*}{ Autumn } & \multirow{11}{*}{ Shoot } & MK461044 & Arthrinium arundinis_IS3-2 & $\mathrm{A}$ & & & & & & & & & & & \\
\hline & & & MK460967 & Ascomycota sp._ISK3-7 & $\mathrm{A}$ & & & & & & & & & & & \\
\hline & & & MK460946 & Aureobasidium pullulans_ISKI-14 & $\mathrm{A}$ & & & & & & & & & & & \\
\hline & & & MK461049 & Emericellopsis sp._IS3-7 & $\mathrm{A}$ & & & & & & & & & & & \\
\hline & & & MK460952 & Epicoccum nigrum_ISK2-5 & $\mathrm{A}$ & & & & & & & & & & & \\
\hline & & & MK460956 & Epicoccum nigrum_ISK2-9 & $\mathrm{A}$ & & & & & & & & & & & \\
\hline & & & MK460966 & Epicoccum nigrum_ISK3-5 & $\mathrm{A}$ & & & & & & & & & & & \\
\hline & \multirow{4}{*}{ Spring } & & MK460938 & Epicoccum sp._ISK1-6 & $\mathrm{A}$ & & & & & & & & & & & \\
\hline & & & MK461031 & Porostereum spadiceum_IS2-6 & $\mathrm{B}$ & & & & & & & & & & & \\
\hline & & & MK461054 & Stemphylium $s p . \_I S 3-12$ & $\mathrm{~A}$ & & & & & & & & & & & \\
\hline & & & MK460969 & Stereum gausapatum_ISK3-11 & B & & & & & & & & & & & \\
\hline & \multirow{2}{*}{ Autumn } & \multirow{5}{*}{ Root } & MK461077 & Acremonium sp._IR2-6 & A & & & & & & & & & & & \\
\hline & & & MK460994 & Aureobasidium pullulans_ISR2-10 & $\mathrm{A}$ & & & & & & & & & & & \\
\hline & \multirow{3}{*}{ Spring } & & MK461090 & Coprinellus domesticus_IR3-9 & B & & & & & & & & & & & \\
\hline & & & MK461086 & Emericellopsis maritima_IR3-5 & A & & & & & & & & & & & \\
\hline & & & MK461007 & Epicoccum nigrum_ISR3-14 & $\mathrm{A}$ & & & & & & & & & & & \\
\hline & \multicolumn{4}{|c|}{ TOTAL POSITIVE } & & 17] & \begin{tabular}{|l|l|l|l}
24 & 3 \\
\end{tabular} & 9 & \begin{tabular}{l|l}
39 & 2 \\
\end{tabular} & $927]$ & \begin{tabular}{l|l}
5 & 2 \\
\end{tabular} & 2729 & & & & \\
\hline
\end{tabular}

Fig. 3 Plant growth promoting properties of 39 endophytic fungal strains associated with $S$ europaea. The color key determines the level of activity expressed by the strains and the measures (Wact
“*” and $\mu \mathrm{g} / \mathrm{ml}$ "***”) used to calculate their activity. Abbreviations used: Ascomycota "A" and Basidiomycota "B" and amylolytic activities ( $\mathrm{W}_{\text {act }}$ ranging from 1 to 10 ; $60 \%$ isolated strains from shoot and $62 \%$ from root). Whereas the strains from S2 possessed proteolytic (90\% isolated strains from shoot and $100 \%$ from root), lipolytic $\left(\mathrm{W}_{\mathrm{act}}<10,100 \%\right.$ isolated strains from both organs), and chitinolytic activities ( $\mathrm{W}_{\text {act }}$ $<10 ; 90 \%$ from shoot and $83 \%$ from root). The strains isolated from the S. europaea shoots from $\mathrm{S} 2\left(\mathrm{~W}_{\text {act }}\right.$ value $\left.>25\right)$ and the roots from $\mathrm{S} 1\left(\mathrm{~W}_{\mathrm{act}}\right.$ value ranging from 10 to $>25$ ) exhibited very high proteolytic activity. The pectolytic activity was comparatively lower $\left(\mathrm{W}_{\text {act }}\right.$ value $\left.<1\right)$ in all cases.

The strains A. pullulans CSK1-11, A. pullulans CSK1-9, A. pullulans ISK1-14 and Sarocladium sp. CR3-2 displayed $\mathrm{W}_{\text {act }}$ value $>25$ for cellulolytic activity. Similarly, very high proteolytic activity $\left(\mathrm{W}_{\text {act }}>20\right)$ was exhibited by a few strains e.g. Sarocladium sp. CR3-2, Ascomycota ISK3-7, Stereum gausapatum ISK3-11, Epicoccum nigrum ISK2-5, Epicoccum sp. ISK1-6, Porostereum spadiceum IS2-6, and Stemphylium sp. 
IS3-12. Some strains: Aureobasidium sp. CSK3-6 and 5 strains of A. pullulans CSK1-9, CSK1-11, CSK3-1, ISK1-14 and ISR2-10 were positive for all tested activities. Some others were negative for most of the activities including the genera Coprinellus domesticus IR3-9, Coprinellus ellisii CS1-21 and A. arundinis CR2-4. Overall, the positive enzyme activities exhibited by the fungal strains in increasing order from S1were: protease $>$ lipase $>$ chitinase $>$ amylase $>$ cellulase $>$ pectinase and from S2 were: lipase $>$ protease $>$ chitinase $>$ cellulase $>$ amylase $>$ pectinase.

Effect of salt on the growth of endophytic fungi

The 39 endophytic fungal strains were cultivated in PDA enriched with different $\mathrm{NaCl}$ salt concentrations and the average mycelium diameter was measured as shown in Fig. 3. All the fungal strains exhibited varying salt tolerance capabilities. The fungal strains in S1 $(63 \%)$ displayed higher salt tolerance $(>700 \mathrm{mM} \mathrm{NaCl})$ than the strains from S2 (17\%). Many strains tolerated salt concentrations of more than $700 \mathrm{mM} \mathrm{NaCl}$ (A. arundinis: CS1-14, CS2-15, CR1-10, CR2-4 and IS3-2; Trichoderma atroviride CSK3-13, Trichoderma citrinoviride CR1-1, T. harzianum CR2-3, Trichoderma sp. CR3-5, Porostereum spadiceum IS2-6, Stemphylium sp. IS3-12, C. ellisii CS1-21 and C. domesticus IR3-9) and the diameter of their mycelia measured on agar was similar to their control without salt. Meanwhile, a few strains proliferated at $500 \mathrm{mM} \mathrm{NaCl}$ (A. pullulans CSK1-11, Podospora sp. CSK2-13, Emericellopsis sp. IS3-7 and Acremonium sp. IR2-6) when compared to their no-salt controls. Only the fungal strain E. nigrum ISR3-14 found in the roots of S2 showed decreasing growth of mycelium in the presence of $\mathrm{NaCl}$ salt.

Growth of $L$. perenne inoculated with endophytic fungi

Based on the results obtained from the metabolic and enzyme activities of the strains, we selected six representative strains: $S$. gausapatum ISK3-11, E. nigrum ISR3-14, A. pullulans CSK1-11, C. ellisii CS1-21, Sarocladium strictum CSR1-13 and Arthrinium gamsii CR1-9 for inoculating two varieties of $L$. perenne. Seven weeks after inoculation with six different fungal isolates, positive effects on the growth of the two L. perenne seed varieties were observed. Two-way ANOVA analysis (Fig. 4) revealed that the six fungal isolates positively influenced the overall growth of
Variety 1 (Epichloë free- $\mathrm{E}^{-}$) including a significant increase in length, fresh and dry weights of the shoots and roots when compared to their non-inoculated control. However, in the case of Variety 2 (Epichloë infected- $\mathrm{E}^{+}$), significant positive differences were consistently seen in fungal strains $S$. gausapatum ISK3-11 (fresh and dry weights) and A. gamsii CR1-9 (for all growth parameters) in the shoots and roots in contrast to their non-inoculated control.

\section{Discussion}

Culturable diversity of endophytic fungi in S. europaea

Most of the endophytic fungi obtained from this halophyte are known plant pathogens and saprobes in other plants. For example, of the dominant and abundantly distributed genera in our study, Alternaria causes leaf blight or leaf spot (Thomma 2003), Phoma causes disease in citrus and oilseed rape (Aveskamp et al. 2008), while Aspergillus causes blights in most plants (Pryor and Michailides 2002). Some saprobes found in this study include Epicoccum, Alternaria, Fusarium, Cladosporium, Penicillium, Acremonium and Aspergillus (Fisher and Petrini 1992; Thongkantha et al. 2008). However, we suppose that these endophytic fungi in halophytes may have "co-evolved" in their host. A high colonization frequency of these endophytes in healthy halophyte plant tissue indicates they are not pathogenic. A few studies have discussed the abilities of fungi to switch lifestyles between the endophyte-pathogen (Fisher and Petrini 1992; Hyde and Soytong 2008) and endophyte-saprotroph (Hyde and Soytong 2008; Promputtha et al. 2010). Many endophytes and pathogenic fungi can persist as saprobes (as a mode of nutrition) once their host plant reaches senescence or leaves abscise (Hyde and Soytong 2008; Promputtha et al. 2010). The entry of pathogens and saprotrophs in halophytes could also be an "escape strategy" to avoid the high salt concentrations in the soil.

The majority of the culturable fungal diversity was classified as Ascomycota and a fraction as Basidiomycota. This finding is comparable to our previous study where sequencing techniques indicated that Ascomycota with Pleosporaceae were the dominant family in all samples from the same sites and seasons in this study (Furtado et al. 2019). The metagenomic study concluded that Paradendryphiella sp. was the more frequently 


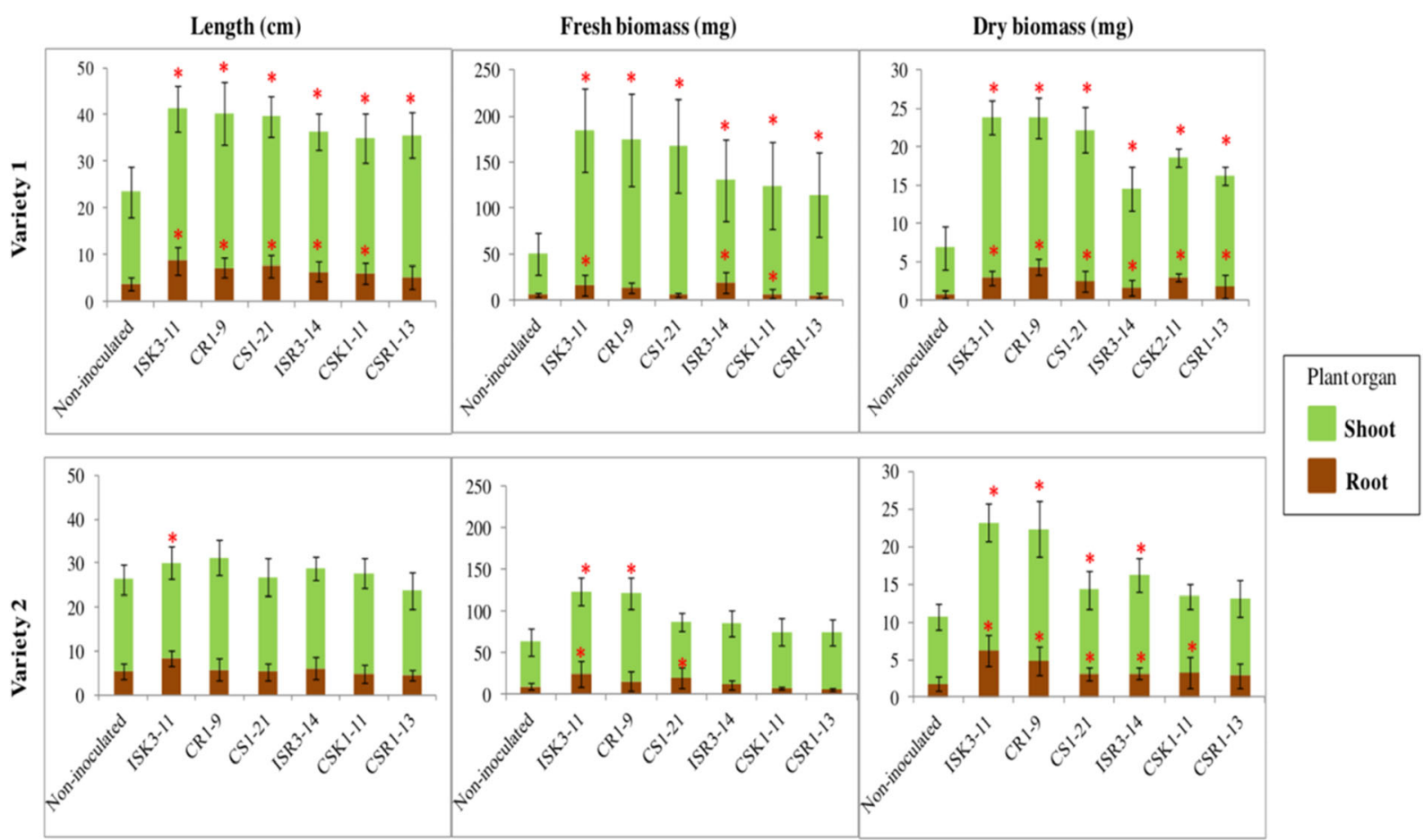

Fig. 4 Effect of different endophytic fungal strains on the growth of Lolium perenne. Two grass varieties: Variety 1 (Epichloë free: $\mathrm{E}^{-}$) and Variety 2 (Epichloë infected: $\mathrm{E}^{+}$) were inoculated with fungal strains. The longest leaf and root is the measurement for

present endophyte of $S$. europaea in both sites, followed by the occurrence of Alternaria sp. (Furtado et al. 2019) while this study using culturable techniques showed $67.9 \%$ of the isolates comprised the genus Alternaria sp. The dominance of Alternaria sp. (Ascomycota) in S. europaea was previously reported in Canada (Muhsin and Booth 1987), Japan (Okane and Nakagiri 2015), South Korea (You et al. 2014) and India (Kannan et al. 2014). However, Alternaria may not be a dominating species in all halophytes: a few examples include Artemisia fukudo, Carex scabrifolia, Kochia scoparia, Phragmites communis, Suaeda australis and $S$. japonica found in the Suncheon bay in South Korea (Young-Hyun et al. 2012); Acanthus ilicifolius, Arthrocnemum indicum, Suaeda maritima and Sesuvium portulacastrum from mangroves in India (Suryanarayan and Kumaresan 2000); and S. maritima, Limonium tetragonum, Suaeda australis, Phragmites australis, and Suaeda glauca from Muan salt marsh of South Korea (Khalmuratova et al. 2015). Fungal endophyte colonisation of the plant may depend on the plant host (Salicornia accumulates salts in its tissue) and the soil characteristics (level of salinity) at the location indicating plant length. The bars indicate the mean $\pm \mathrm{SE}=12$ plant replicates. "*"- Significant differences observed in comparison to non-inoculated plants (control)

(Maciá-Vicente et al. 2012). Indeed, the highest frequency of fungal colonisation occurred in Aster tripolium roots, followed by Limonium angustifolium and S. europaea, which are the most abundant halophytic plant species from Sečovlje salterns (Slovenia) (Sonjak et al. 2009). Notably, some species e.g. Trichoderma sp., Phoma betae, Fusarium sp., Emericellopsis sp., Epicoccum nigrum, Alternaria sp., Lewia sp., Pleosporales sp., Cladosporium sp. and Stemphylium sp. were previously reported endophytes of $S$. europaea found near a lakeside in Japan (Okane and Nakagiri 2015). Most of these reports on S. europaea endophytes present in roots do not indicate the plant growth stage at which the diversity analysis was carried out. Conversely, our study analyzes the whole plant (shoot and root) for fungal endophyte diversity and considers the plant growth stage ( $S$. europaea samples were collected in both spring and autumn, in young and mature plants).

Besides the influence of the host plant, environmental effects were considered by selecting two sites with different sources of salinity. Most endophytes originate from the soil and enter the plant through cracks, wounds, root hairs or stomata in leaves 
(Mercado-Blanco 2015). The occurrences of certain endophytic and rhizospheric fungal communities in roots of a halophyte and non-halophyte plant were positively correlated to the differing soil salinities (Maciá-Vicente et al. 2012). Site S1 of our study was characterised as a highly saline site (high electrical conductivity, $\mathrm{EC}_{\mathrm{e}}$ ) with more $\mathrm{Na}^{+}$ions in the soil and a longer duration of salinisation than Site S2 (lower $\mathrm{EC}_{\mathrm{e}}$ and more $\mathrm{Ca}^{+}$ions found in soil) (Furtado et al. 2019; Szymańska et al. 2014). Some genera were detected at one site only. Plants at site S1 hosted Fusarium sp., Phaeosphaeriaceae sp., Trichoderma sp., Ascochyta sp., Peniophora sp., Sarocladium sp., Ceriporia sp., Cladophialophora sp., Coriolopsis sp., Fusicolla sp., Phanerochaete sp., Podospora sp., and Thanatephorus sp. Conversely, Eurotium sp., Emericellopsis sp., Dematiopleospora sp., Nectria sp., Porostereum sp. and Stereum sp. were only isolated from S2. Most of these fungal isolates were halophilic and/or halotolerant to $\mathrm{NaCl}$ salt, and demonstrated high salt tolerance ability to concentrations up to $500 \mathrm{mM} \mathrm{NaCl}$ while a few isolates showed tolerance at $700 \mathrm{mM} \mathrm{NaCl}$. Thus the type and concentration of salinity in the soil can influence the microbial niche at the site and its cellular metabolic rate to tolerate salts (Collado et al. 1999; Lembicz and Olejniczak 2009). Some strains detected in our study can be categorised as black fungi or dematiaceous fungi, such as the genera Alternaria, Phoma, Cladosporium, Lewia, Pleospora, Epicoccum, Stemphylium, Ascochyta, Plenodomus, Neocamarosporium, Dematiopleospora, Aspergillus, Penicillium, Eurotium, Talaromyces, Fusarium, and Aureobasidium. Species of dematiaceous fungi are morphologically plastic. Their cell walls contain melanin, they possess some protective substances and are capable of tolerating extreme temperatures, desiccation and saline environments (Gostinčar et al. 2010). These fungi can mitigate stress in plants (Selbmann et al. 2005) and may play a protective role in the halophyte in our study. These dematiaceous fungi have been previously isolated from halophytes found in an inland sea (e.g. $S$. europaea), intertidal regions (e.g. Avicennia marina), salt marshes (e.g. Arthrocnemum macrostachum, Halocnemum strobilecium, Limonastrum monopetalum, Zygophyllum album, and Z. simplex) and salt-affected land (e.g. Tamarix nilotica, Zilla spinosa and Z. coccineum), and alkaline soils (e.g.
Suaeda sp.) (El-Morsy 2000; Okane and Nakagiri 2015; Sun et al. 2011a, b).

Furthermore, fungal diversity changed from one season to another. The fungal strain collection from both the sites was more diverse (based on genus level classification) in spring than in autumn. Certain genera (e.g. Aureobasidium, Cladosporium, Epicoccum and Talaromyces) occurred only in the autumn sampling, while Neocamarosporium, Ascochyta and Acremonium were obtained only in spring. The ease of fungal colonisation in the young host plant stage (during spring), and the fungi's potency to compete for survival in their host may account for this seasonal effect. Similarly, endophytic populations of Heterosmilax japonica were more diverse during spring than in autumn (Gao et al. 2005).

Fungal properties give a clue to their potential function in the host

Abiotic stresses (e.g. salinity) limit plant growth and at times this damage is irreversible. In such circumstances, the endophytic fungi can facilitate plant growth and development in multiple ways, by producing polyamines (Fan et al. 2014), or phytohormones such as auxins (Bose et al. 2014); synthesising fungal siderophores (Bartholdy et al. 2001); solubilising phosphates (Barrow and Osuna 2002); producing inhibitory substances or antimicrobial compounds; or synthesising degrading enzymes (Rajesh and Ravishankar Rai 2013). Plant growth promotion by endophytic fungi occurs in several crops including wheat (Dingle and Mcgee 2003), dwarf mutant Waito- $C$ and Dongjin-beyo rice (Waqas et al. 2012), and barley (Waller et al. 2005). Although the metabolic and enzyme activities measured in this study were from experiments conducted under ideal conditions, production of metabolites or enzymes may differ in soils with a high $\mathrm{EC}_{\mathrm{e}}$ and other environmental stresses.

Soil salinity not only affects microbial community composition and abundance but also affects microbial functions, i.e. enzymatic and metabolic processes (Morrissey et al. 2014; Rath et al. 2016). High salinity can reduce microbial enzyme activity (Singh 2016). All fungi possess pathways to biosynthesise polyamines, which are important in restoring cellular homeostasis under stressful conditions (Nikolaou et al. 2009; ValdésSantiago and Ruiz-Herrera 2014). The endophytic fungal strains isolated from the S. europaea shoots actively 
produced polyamines. This activity can be correlated with shoot hyper-accumulation of salts in Salicornia, which is more stressful for fungal colonisation than in the roots. Furthermore, the fungal polyamines are involved in many cellular maintenance processes in the host plant as well as functioning in plant growth promotion (Amprayn et al. 2012). Additionally, siderophores production by fungi is one of the biocontrol mechanisms observed in most of the Salicornia endophytic strains. The ability of the fungi to chelate iron makes them better competitors thus preventing the growth of pathogenic microorganisms in plant hosts (Johnson 2008). Siderophores also play a role in stimulating induced systemic resistance (ISR) while fungal siderophores modulate iron homeostasis in Epichloëfestucae infected ryegrass plants (Hardoim et al. 2015; Johnson et al. 2013). Furthermore, fungi enhance the growth of host plants by producing phytohormones, mainly IAA (Shi et al. 2009; Waqas et al. 2012). IAA increases the colonisation efficiency of endophytic bacteria and may have a similar function in fungi (Suzuki et al. 2003). In the host Artemis annua, the endophytic fungus Colletotrichum sp. produced substances like IAA to regulate plant processes ( $\mathrm{Lu}$ et al. 2000). In another study, Trichoderma virens displayed characteristic auxin-related phenotypes such as increased plant biomass and stimulated lateral root development in Arabidopsis, but mutations in auxin biosynthesis genes reduced the effects of $T$. virens inoculation (ContrerasCornejo et al. 2009). Interestingly, the relatively low capacity of endophytic fungi to produce auxins in our study suggests that this is not the main mechanism by which it affects halophyte growth. Most IAA synthesising fungi were mainly isolated from the roots of the host plant in our study. Conversely, no fungal strains could solubilise phosphate. Phosphate solubilisation ability could be adversely influenced by environmental factors, especially under stress conditions. For instance, during the summer when the soil was simultaneously exposed to high salt, high $\mathrm{pH}$ and high-temperature stress, bacteria growing in alkaline soils in India demonstrated diverse levels of phosphate solubilisation ability and poor growth of phosphate solubilising bacteria (Nautiyal et al. 2000). There is no subsequent evidence on the effects of fungal phosphate solubilisation from salt stress environments.

Our study supposed that the fungal endophytes potentially regulated halophyte growth by improving plant nutrition and catalyzing different biochemical processes by the action of fungal enzymes such as cellulase, pectinase, chitinase, amylase, protease, and lipase (Choi et al. 2005). The enzymes cellulase, chitinase, and amylase, produced by most of the strains, are important for endophyte colonisation (Caldwell et al. 2000). Therefore, the capability of endophytic fungi to produce enzymes to degrade cellulose and lignin is also a possible strategy to allow some endophytes to decay host tissue and persist as saprobes after host senescence (Lumyong et al. 2002; Oses et al. 2008). Endophytic fungal strains producing chitinase and protease may enhance toxicity against plant pathogens including insects, pests and nematodes (Kredics et al. 2005; Viterbo et al. 2002). For example, Trichoderma is among the well-studied species known to produce these enzymes that parasitise cell walls or hyphae of many plant pathogens (Kredics et al. 2005; Viterbo et al. 2002). A similar role may be played by the enzymes cellulases, pectinases, amylases, and protease to suppress plant pathogen activities directly, and these can degrade the cell walls of pathogenic fungi and oomycetes (Gao et al. 2010; Yarullina et al. 2016). In this study, the multifunctional lifestyle of all the strains of genus Aureobasidium was evidenced by a broad-spectrum of enzyme activities, unlike the genus Coprinellus.

Beneficial associations between plants and endophytic microbial communities play an important role in both natural and agricultural ecosystems (Cheplick 2004; Rodriguez et al. 2004, Redman et al. 2005). Our data did, however, support the hypothesis of variations in the properties of endophytes between different genera, sites and plant organs. The activity of endophytes from S2 (lower salinity) was higher than observed at S1 (higher salinity). Moreover, we suggest that duration of soil salinisation at the two sites (salinity has existed at S1 much longer than at S2) could disturb the metabolic function of microorganisms. Variations in the metabolic and enzyme activities among similar endophytic fungal species isolated from different conditions were seen in Epiccocum sp., Arthrinium sp. and Trichoderma sp. The information on the contribution of environmental factors in the fungal endophyte distribution and composition in $S$. europaea was previously discussed in Furtado et al. 2019.

Salicornia endophytic fungi promote growth in non-host plants

Advantageously, Salicornia endophytes are well adapted to extreme conditions, so they can be applied 
to salt-stressed plants as growth promoting agents. In our collection of characterised fungal isolates, we selected six endophytes that exhibited most of the tested activities for inoculation: S. gausapatum ISK3-11, E. nigrum ISR3-14, A. pullulans CSK1-11, C. ellisii CS1-21, S. strictum CSR1-13 and A. gamsii CR1-9. These fungal strains are regarded as plant promoting fungi e.g. the strain Aureobasidium pullulans has been effective in the control of sour rot of citrus, by producing chitinase enzyme against the phytopathogen (Ferraz et al. 2016). A. pullulans has several mechanisms against plant pathogens (Bencheqroun et al. 2007) including the production of antifungal compounds (Zhang et al. 2012), volatile and cell-free compounds (Di Francesco et al. 2015), killer toxins (Ferraz et al. 2016) and the antibiotic aureobasidin A (AbA) (Liu et al. 2007), and the induction of plant defence responses (Ippolito et al. 2000). Endophyte Epicoccum sp. isolated from Taxus fauna possessed novel antimicrobial compounds against Staphylococcus aureus (ATCC6538) and Candida albicans (CI.I 4043) (Jadoon et al. 2016). Another in vitro experiment revealed increased enzymatic activity of Epiccocum sp. in rice leaf blast suppression against rice pathogens (Sena et al. 2013). Sarocladium strictum (also named Acremonium strictum) and Acremonium gamsii were the other two strains used in our study. Acremonium species are common symbionts in tall fescue grass and confer drought tolerance in grasses (White et al. 1992). The association of Acremonium endophytes can ameliorate biotic stress in grass species e.g. Lolium perenne and Festuca longifolia against the larvae of autumn armyworm, green bug and yellow sugarcane aphids (Breen 1993a, b). The Coprinellus species isolated from the Brazilian medicinal plant Solanum cernuum exhibited antibacterial activities (Vieira et al. 2012). It is a basidiomycetous genus and some of its species were obtained as endophytes of coastal grasses and forest trees Theobroma gileri (Márquez et al. 2008; Thomas et al. 2008). Lastly, $S$. gausapatum collected from oak forest and orchards in southern Serbia displayed high lignin-degrading abilities and the efficiency of lignin removal from beech wood sawdust (Jović et al. 2018). Not much information was reported on the plant growth promoting abilities of this strain.

In our study, the six representative endophytic fungal strains from $S$. europaea displayed positive compatible associations and confirmed plant growth promoting traits in the non-host ryegrass. Similar results demonstrated the positive effects of bacterial endophytes from S. europaea in Beta vulgaris grown under different salt concentrations (Piernik et al. 2017), thus confirming them as inoculants for plant growth promotion. Under controlled growth conditions, Variety $1\left(\mathrm{E}^{-}\right)$ inoculated with Salicornia endophytes significantly increased shoot and root length, and wet and dry weights compared to non-inoculated controls. Conversely, in Variety $2\left(\mathrm{E}^{+}\right)$only strains $S$. gausapatum ISK3-11 and A. gamsii CR1-9 were significantly consistent in promoting plant growth. The variety 2 was symbiotically associated with endophytic fungi Epichloë (known as Neotyphodium sp.), that may have disturbed the colonization of some of the inoculated fungal strains in this experiment, with the exception of $S$. gausapatum ISK311 and A. gamsii CR1-9 strains that were not affected (Schardl et al. 2004). Similar results were obtained where inoculation and colonization of fungi Ascochyta leptospora in perennial ryegrass was not inhibited in the presence of symbiotic fungi Epichloë festucae (Tian et al. 2008).

\section{Conclusion}

Colonisation of fungi in $S$. europaea depends on host plant lifestyle (Salicornia is known to accumulate salts in its shoot) and the type of soil at the site (natural and anthropogenic salinity). Most of the identified endophytic fungi (94\%) were known plant pathogens and saprobes in other plants, which highlights the ability of fungi to switch lifestyles and co-evolve in their hosts. Salicornia endophytic fungi were confirmed as mainly halotolerant and possess enzymes and metabolic traits that might improve growth and development of the hostplant. Endophytes of $S$. europaea actively produce siderophores, and polyamines, and have cellulolytic, proteolytic, lipolytic and chitinolytic activities. Among the selected strains, Aureobasidium spp. displayed broad-spectrum activities, proving its multifunctional lifestyle. Enzyme and metabolic activities of fungal endophytes isolated from the anthropogenically saline site were higher than those from the site with naturally high soil salinity, highlighting that salinity levels affect microbial activity. Only two strains out of the six fungal strains inoculated in non-host L. perenne exhibited compatible and beneficial associations in the two grass varieties. We can infer that the presence of native microbiota in plants affects the inoculated strains which may 
be due to some inhibitory response or competition from the native endophyte, which needs further investigation. Two fungal strains, S. gausapatum ISK3-11 and A. gamsii CR1-9, significantly improved plant growth.

Acknowledgments We thank Niels Roulund (DLF Seeds A/S, Denmark) for providing the seed varieties of Lolium perenne for the experiment. The authors are grateful to the BestPass (Boosting plant-endophyte stability, compatibility and performance across scales) consortium for their valuable inputs.

Author contribution BF did all analyses and wrote the first version of the manuscript. SSz prepared the sequencing data and the statistical data. KH designed and managed field and lab experiments as well as participated in the preparation of the manuscript. All authors revised the manuscript and approved the publication.

Funding This project has received funding from the European Union's Horizon 2020 research and innovation programme under the Marie Skłodowska-Curie grant agreement No. 676480.

\section{Compliance with ethical standards}

Competing interests The authors declare that they have no competing interests.

Data deposition The DNA sequences files were submitted to GenBank SUB5097742 and accession numbers were assigned: MK460774 - MK461093.

Ethics statements Not applicable.

Open Access This article is distributed under the terms of the Creative Commons Attribution 4.0 International License (http:// creativecommons.org/licenses/by/4.0/), which permits unrestricted use, distribution, and reproduction in any medium, provided you give appropriate credit to the original author(s) and the source, provide a link to the Creative Commons license, and indicate if changes were made.

\section{References}

Agrawal T, Kotasthane AS (2012) Chitinolytic assay of indigenous Trichoderma isolates collected from different geographical locations of Chhattisgarh in Central India. Springer plus 1:73. https://doi.org/10.1186/2193-1801-1-73

Alexander DB, Zuberer DA (1991) Use of chrome azurol S reagents to evaluate siderophore production by rhizosphere bacteria. Biol Fertil Soils 12:39-45. https://doi.org/10.1007 /BF00369386
Amprayn K, Rose MT, Kecskés M, Pereg L, Nguyen HT, Kennedy IR (2012) Plant growth promoting characteristics of soil yeast (Candida tropicalis HY) and its effectiveness for promoting rice growth. Appl Soil Ecol 61:295-9. https://doi. org/10.1016/J.APSOIL.2011.11.009

An H, Liu Y, Zhao X et al (2015) Characterization of cadmiumresistant endophytic fungi from Salix variegata Franch. In three gorges reservoir region, China. Microbiol Res 176:2937. https://doi.org/10.1016/J.MICRES.2015.03.013

Arnold AE, Carlos Mejía L, Kyllo D et al (2003) Fungal endophytes limit pathogen damage in a tropical tree. PNAS 100: 15649-15654. https://doi.org/10.1073/pnas.2533483100

Aveskamp MM, de Gruyter J, Crous PW (2008) Biology and recent developments in the systematics of Phoma, a complex genus of major quarantine significance. Fungal Divers 31:118

Barrow JR, Osuna P (2002) Phosphorus solubilization and uptake by dark septate fungi in fourwing saltbush, Atriplex canescens (Pursh) Nutt. J Arid Environ 51:449-459. https://doi.org/10.1006/jare.2001.0925

Bartholdy BA, Berreck M, Haselwandter K (2001) Hydroxamate siderophore synthesis by Phialocephala fortinii, a typical dark septate fungal root endophyte. BioMetals 14:33-42. https://oi.org/10.1023/A:1016687021803

Bencheqroun SK, Bajji M, Massart S et al (2007) In vitro and in situ study of postharvest apple blue mold biocontrol by Aureobasidium pullulans: evidence for the involvement of competition for nutrients. Postharvest Biol Technol 46:128135 . ht t p s://doi.org/10.1016/J . POSTHARVBIO.2007.05.005

Berg B, Pettersson G (1977) Location and formation of cellulases in Trichoderma viride. J Appl Bacteriol 42:65-75. https://doi. org/10.1111/j.1365-2672.1977.tb00670.x

Bilal L, Asaf S, Hamayun M et al (2018) Plant growth promoting endophytic fungi Aspergillus fumigatus TS1 and Fusarium proliferatum BRL1 produce gibberellins and regulates plant endogenous hormones. Symbiosis 76:117-127. https://doi. org/10.1007/s13199-018-0545-4

Bose A, Shah D, Keharia H (2013) Production of indole-3-aceticacid (IAA) by the white rot fungus Pleurotus ostreatus under submerged condition of Jatropha seedcake. Mycol An Int J Fungal Biol 4:103-111. https://doi.org/10.1080 /21501203.2013.823891

Bose J, Rodrigo-Moreno A, Shabala S (2014) ROS homeostasis in halophytes in the context of salinity stress tolerance. J Exp Bot 65:1241-1257. https://doi.org/10.1093/jxb/ert430

Breen JP (1993a) Enhanced resistance to fall armyworm (Lepidoptera: Noctudiae) in Acremonium endophyteinfected turfgrasses. J Econ Entomol 86:621-629. https://doi.org/10.1093/jee/86.2.621

Breen JP (1993b) Enhanced resistance to three species of aphids (Homoptera: Aphididae) in Acremonium endophyte-infected turfgrasses. J Econ Entomol 86:1279-1286. https://doi. org/10.1093/jee/86.4.1279

Caldwell BA, Jumpponen A, Trappe JM (2000) Utilization of major detrital substrates by dark-septate, root endophytes. Mycologia 92:230-232. https://doi.org/10.2307/3761555

Cheplick GP (2004) Recovery from drought stress in Lolium perenne (Poaceae): are fungal endophytes detrimental? Am J Bot 91:1960-1968. https://doi.org/10.3732/ajb.91.12.1960 
Choi YW, Hodgkiss IJ, Hyde KD (2005) Enzyme production by endophytes of Brucea javanica. Water:55-66

Clay K (1990) Fungal endophytes of grasses. Annu Rev Ecol Syst 2163180147:275-297. https://doi.org/10.1146/annurev. es.21.110190.001423

Cloete KJ, Valentine AJ, Stander MA et al (2009) Evidence of symbiosis between the soil yeast Cryptococcus laurentii and a sclerophyllous medicinal shrub, Agathosma betulina (Berg.) Pillans. Microb Ecol 57:624-632. https://doi. org/10.1007/s00248-008-9457-9

Collado J, Platas G, Gonzalez I, Pelaaez F (1999) Geographical and seasonal influences on the distribution of fungal endophytes in Quercus ilex. New Phytol 144:525-532. https://doi. org/10.1046/j.1469-8137.1999.00533.x

Contreras-Cornejo HA, Macías-Rodríguez L, Cortés-Penagos C, Ló Pez-Bucio J (2009) Trichoderma virens, a plant beneficial fungus, enhances biomass production and promotes lateral root growth through an auxin-dependent mechanism in Arabidopsis. Plant Physiol Biochem 149:1579-1592. https://doi.org/10.1104/pp.108.130369

Di Francesco A, Roberti R, Martini C et al (2015) Activities of Aureobasidium pullulans cell filtrates against Monilinia laxa of peaches. Microbiol Res 181:61-67. https://doi. org/10.1016/J.MICRES.2015.09.003

Dingle J, Mcgee PA (2003) Some endophytic fungi reduce the density of pustules of Puccinia recondita f. sp. tritici in wheat. Mycol Res 107:310-316. https://doi.org/10.1017 /S0953756203007512

El-Morsy E-SM (2000) Fungi isolated from the endorhizosphere from the red sea coast of Egypt of halophytic plants. Fungal Divers 5:43-54

Faeth SH, Fagan WF (2002) Fungal endophytes: common host plant symbionts but uncommon mutualists. Integr Comp Biol 42:8. https://doi.org/10.1093/icb/42.2.360

Fan G, Liu Y, Wang X, Zhan Y (2014) Cross-talk of polyamines and nitric oxide in endophytic fungus-induced betulin production in Betula platyphylla plantlets. Trees 28:635-641. https://doi.org/10.1007/s00468-014-0978-1

Felsenstein J (1985) Confidence limits on phylogenies: an approach using the bootstrap. Evolution (N Y) 39:783-791. https://doi.org/10.1111/j.1558-5646.1985.tb00420.x

Ferraz LP, da Cunha T, da Silva AC, Kupper KC (2016) Biocontrol ability and putative mode of action of yeasts against Geotrichum citri-aurantii in citrus fruit. Microbiol Res 188-189:72-79. https://doi.org/10.1016/J. MICRES.2016.04.012

Fisher PJ, Petrini O (1992) Fungal saprobes and pathogens as endophytes of rice (Oryza sativa L.). New Phytol 120:137143. https://doi.org/10.1111/j.1469-8137.1992.tb01066.x

Furtado BU, Gołębiewski M, Skorupa M et al (2019) Bacterial and fungal endophytic microbiomes of Salicornia europaea. Appl Environ Microbiol. https://doi.org/10.1128 /AEM.00305-19

Ganley RJ, Brunsfeld SJ, Newcombe G (2004) A community of unknown, endophytic fungi in western white pine. Proc Natl Acad Sci U S A 101:10107-10112. https://doi.org/10.1073 /pnas.0401513101

Gao X-X, Zhou H, Xu D-Y et al (2005) High diversity of endophytic fungi from the pharmaceutical plant, Heterosmilax japonica Kunth revealed by cultivation-independent approach. FEMS Microbiol Lett 249:255-266. https://doi. org/10.1016/j.femsle.2005.06.017

Gao FK, Dai CC, Liu XZ (2010) Mechanisms of fungal endophytes in plant protection against pathogens. Afr J Microbiol Res 4:1346-1351

Germain SG, Summerbell R (2010) Identifying filamentous fungi. A clinical laboratory handbook, 2nd edn. Star Publishing Co, Belmont, 386p

Gibson T, Gordon RE (1974) Genus I Bacillus. In: Buchnon RE, Gobbons NE (eds) Bergey's manual of determinative bacteriology. The Williams and Wilkins Co., Baltimore, pp 529550

Gopi K, Jayaprakashvel M (2017) Endophytic fungi from halophytes and their antioxidant potential. Res J Pharm Tech 10. https://doi.org/10.5958/0974-360X.2017.00745.4

Gordon SA, Weber RP (1951) Colorimetric estimation of indoleacetic acid. Plant Physiol 26:192-195. https://doi. org/10.1104/pp.26.1.192

Gostinčar C, Grube M, De Hoog S et al (2010) Extremotolerance in fungi: evolution on the edge. FEMS Microbiol Ecol 71:211. https://doi.org/10.1111/j.1574-6941.2009.00794.x

Groppe K, Steinger T, Sanders II et al (1999) Interaction between the endophytic fungus Epichloe bromicola and the grass Bromus erectus: effects of endophyte infection, fungal concentration and environment on grass growth and flowering. Mol Ecol 8:1827-1835. https://doi.org/10.1046/j.1365-294 X.1999.00772.X

Hardoim PR, van Overbeek LS, Berg G et al (2015) The hidden world within plants: ecological and evolutionary considerations for defining functioning of microbial endophytes. Microbiol Mol Biol Rev 79:293-320. https://doi. org/10.1128/MMBR.00050-14

Herre EA, Mejía LC, Kyllo DA et al (2007) Ecological implications of anti-pathogen effects of tropical fungal endophytes and mycorrhizae. Ecology. https://doi.org/10.1890/05-1606

Hrynkiewicz K, Baum C, Leinweber P (2010) Density, metabolic activity, and identity of cultivable rhizosphere bacteria on Salix viminalis in disturbed arable and landfill soils. J Plant Nutr Soil Sci 173:747-756. https://doi.org/10.1002 /jpln.200900286

Hwang J-S, You Y-H, Bae J-J et al (2011) Effects of endophytic fungal secondary metabolites on the growth and physiological response of Carex kobomugi Ohwi. J Coast Res 27:544 548. https://doi.org/10.2112/JCOASTRES-D-10-00090.1

Hyde K, Soytong K (2008) The fungal endophyte dilemma. Fungal Divers 33:163-173

Indira K, Jayaprabha N, Srinivasan M (2015) Antimicrobial activity of endophytic fungi isolated and identified from salt marsh plant in Vellar estuary. J Microbiol Antimicrob 7:1320. https://doi.org/10.5897/JMA2014.0334

Ippolito A, El Ghaouth A, Wilson CL, Wisniewski M (2000) Control of postharvest decay of apple fruit by Aureobasidium pullulans and induction of defense responses. Postharvest Biol Technol 19:265-272. https://doi. org/10.1016/S0925-5214(00)00104-6

Jadoon M, Fatima N, Murtaza S et al (2016) Production of antimicrobial peptides by Epicoccum sp. NFW1: An endophyte of Taxux fauna. Acta Pol Pharm 73:1555-1563

Jha B, Gontia I, Hartmann A (2012) The roots of the halophyte Salicornia brachiata are a source of new halotolerant diazotrophic bacteria with plant growth-promoting potential. 
Plant Soil 356:265-277. https://doi.org/10.1007/s11104-0110877-9

Jia M, Chen L, Xin HL et al (2016) A friendly relationship between endophytic fungi and medicinal plants: a systematic review. Front Microbiol 7:1-14. https://doi.org/10.3389 /fmicb.2016.00906

Johnson L (2008) Iron and siderophores in fungal-host interactions. Mycol Res 112:170-183. https://doi.org/10.1016/J. MYCRES.2007.11.012

Johnson LJ, Koulman A, Christensen M et al (2013) An extracellular siderophore is required to maintain the mutualistic interaction of Epichloë festucae with Lolium perenne. PLoS Pathog 9:e1003332. https://doi.org/10.1371/journal. ppat.1003332

Jović J, Buntić A, Radovanović N et al (2018) Lignin-degrading abilities of novel autochthonous fungal isolates Trametes hirsuta F13 and Stereum gausapatum F28. Food Technol Biotechnol ISSN 1330-9862. https://doi.org/10.17113 /ftb.56.03.18.5348

Kannan KP, Madhan Kumar D, Ramya PR et al (2014) Diversity of endophytic fungi from salt tolerant plants. Int J ChemTech Res 6:4084-4088

Khalmuratova I, Kim H, Nam Y, et al (2015) Mycobiology diversity and plant growth promoting capacity of endophytic fungi associated with halophytic plants from the west coast of Korea. 373-383. https://doi.org/10.5941 /MYCO.2015.43.4.373

Kimmons CA, Gwinn KD, Bernard EC (1990) Nematode reproduction on endophyte-infected and endophyte-free tall fescue. Plant Dis 74:757-761. https://doi.org/10.1094/PD-740757

Kogel KH, Franken P, Hückelhoven R (2006) Endophyte or parasite - what decides? Curr Opin Plant Biol 9:358-363. https://doi.org/10.1016/j.pbi.2006.05.001

Kredics L, Antal Z, Szekeres A et al (2005) Extracellular proteases of Trichoderma species. A review. Acta Microbiol Immunol Hung 52:169-184. https://doi.org/10.1556 /AMicr.52.2005.2.3

Kumar S, Nei M, Dudley J, Tamura K (2008) MEGA: a biologistcentric software for evolutionary analysis of DNA and protein sequences. Brief Bioinform 9:299-306. https://doi. org/10.1093/bib/bbn017

Lembicz M, Olejniczak P (2009) The fungus Epichloë typhina in populations of a halophyte Puccinellia distans: salinity as a possible inhibitor of infection. Acta Soc Bot Pol 78:81-86

Letunic I, Bork P (2016) Interactive tree of life (iTOL) v3: an online tool for the display and annotation of phylogenetic and other trees. Nucleic Acids Res 44:W242-W245. https://doi. org/10.1093/nar/gkw290

Leuchtmann A, Bacon CW, Schardl CL et al (2014) Nomenclatural realignment of Neotyphodium species with genus Epichlö̈. Mycologia 106:202-215. https://doi. org/10.3852/13-251

Liu X, Wang J, Gou P et al (2007) In vitro inhibition of postharvest pathogens of fruit and control of gray mold of strawberry and green mold of citrus by aureobasidin A. Int J Food Microbiol 119:223-229. https://doi.org/10.1016/J. IJFOODMICRO.2007.07.054

Lu H, Zou WX, Meng JC et al (2000) New bioactive metabolites produced by Colletotrichum sp., an endophytic fungus in
Artemisia annua. Plant Sci 151:67-73. https://doi. org/10.1016/S0168-9452(99)00199-5

Lumyong S, Lumyong P, McKenzie EHC, Hyde KD (2002) Enzymatic activity of endophytic fungi of six native seedling species from Doi Suthep-Pui National Park, Thailand. Can J Microbiol 48:1109-1112

Maciá-Vicente JG, Ferraro V, Burruano S, Lopez-Llorca LV (2012) Fungal assemblages associated with roots of halophytic and non-halophytic plant species vary differentially along a salinity gradient. Microb Ecol 64:668-679. https://doi.org/10.1007/s00248-012-0066-2

Manter DK, Vivanco JM (2007) Use of the ITS primers, ITS1F and ITS4, to characterize fungal abundance and diversity in mixed-template samples by qPCR and length heterogeneity analysis. J Microbiol Methods 71:7-14. https://doi. org/10.1016/j.mimet.2007.06.016

Márquez SS, Bills GF, Zabalgogeazcoa I (2008) Diversity and structure of the fungal endophytic assemblages from two sympatric coastal grasses. Fungal Divers 33:87-100. https://doi.org/10.1002/asi.20193

Mendoza AR, Sikora RA (2009) Biological control of Radopholus similis in banana by combined application of the mutualistic endophyte Fusarium oxysporum strain 162, the egg pathogen Paecilomyces lilacinus strain 251 and the antagonistic bacteria Bacillus firmus. BioControl 54:263-272. https://doi. org/10.1007/s10526-008-9181-x

Mercado-Blanco J (2015) Life of microbes inside the plant. In: Lugtenberg B (ed) Principles of plant-microbe interactions. Springer, Cham. https://doi.org/10.1007/978-3-319-085753 _

Morrissey EM, Gillespie JL, Morina JC, Franklin RB (2014) Salinity affects microbial activity and soil organic matter content in tidal wetlands. Glob Chang Biol 20:1351-1362. https://doi.org/10.1111/gcb.12431

Muhsin TM, Booth T (1987) Fungi associated with halophytes of an inland salt marsh, Manitoba, Canada. Can J Bot 65:11371151. https://doi.org/10.1139/b87-159

Nautiyal CS, Bhadauria S, Kumar P et al (2000) Stress induced phosphate solubilization in bacteria isolated from alkaline soils. FEMS Microbiol Lett 182:291-296. https://doi. org/10.1111/j.1574-6968.2000.tb08910.x

Nei M, Kumar S (2000) Molecular evolution and phylogenetics. Oxford university press, New York, p 333

Nikalje GC, Srivastava AK, Pandey GK, Suprasanna P (2017) Halophytes in biosaline agriculture: mechanism, utilization and value addition. L Degrad Dev:1-15. https://doi. org/10.1002/ldr.2819

Nikolaou E, Agriafioti I, Stumpf M et al (2009) Phylogenetic diversity of stress signaling pathways in fungi. BMC Evol Biol 9:44. https://doi.org/10.1186/1471-2148-9-44

Okane I, Nakagiri A (2015) Assemblages of endophytic fungi on Salicornia europaea disjunctively distributed in Japan: towards clarification of the ubiquity of fungal endophytes on halophytes and their ecological roles. Curr Sci 109:62-71

Oses R, Valenzuela S, Freer J et al (2008) Fungal endophytes in xylem of healthy Chileaan trees and their possible role in early wood decay. Fungal Divers 33:77-86

Pan X, Qin Y, Yuan Z (2018) Potential of a halophyte-associated endophytic fungus for sustaining Chinese white poplar growth under salinity. Symbiosis 76:109-116. https://doi. org/10.1007/s13199-018-0541-8 
Piernik A, Hrynkiewicz K, Wojciechowska A et al (2017) Effect of halotolerant endophytic bacteria isolated from Salicornia europaea L. on the growth of fodder beet (Beta vulgaris L.) under salt stress. Arch Agron Soil Sci 00:1-15. https://doi. org/10.1080/03650340.2017.1286329

Pikovskaya RI (1948) Mobilization of phosphorus in soil in connection with vital activity of some microbial species. Microbiology 17:362-370

Porras-Alfaro A, Bayman P (2011) Hidden Fungi, emergent properties: endophytes and microbiomes. Annu Rev Phytopathol 49:291-315. https://doi.org/10.1146/annurev-phyto-080508081831

Pritchard SG (2011) Soil organisms and global climate change. Plant Pathol 60:82-99. https://doi.org/10.1111/j.13653059.2010.02405.x

Promputtha I, Hyde KD, Mckenzie EHC et al (2010) Can leaf degrading enzymes provide evidence that endophytic fungi becoming saprobes? Fungal Divers 41:89-99. https://doi. org/10.1007/s13225-010-0024-6

Pryor BM, Michailides TJ (2002) Ecology and population biology morphological, pathogenic, and molecular characterization of Alternaria isolates associated with Alternaria late blight of pistachio. Phytopathology:402-406. https://doi. org/10.1094/PHYTO.2002.92.4.406

Qin S, Zhang Y-JJ, Yuan B et al (2014) Isolation of ACC deaminase-producing habitat-adapted symbiotic bacteria associated with halophyte Limonium sinense (Girard) Kuntze and evaluating their plant growth-promoting activity under salt stress. Plant Soil 374:753-766. https://doi.org/10.1007 /s11104-013-1918-3

Qin Y, Pan X, Kubicek C, Druzhinina I, Chenthamara K, Labbé J, Yuan Z (2017). Diverse plant-associated pleosporalean fungi from saline areas: Ecological tolerance and nitrogen-status dependent effects on plant growth. Front Microbiol 8:158. https://doi.org/10.3389/fmicb.2017.00158

Rajesh PS, Ravishankar Rai V (2013) Hydrolytic enzymes and quorum sensing inhibitors from endophytic fungi of Ventilago madraspatana Gaertn. Biocatal Agric Biotechnol 2:120-124. https://doi.org/10.1016/j.bcab.2013.01.002

Rath KM, Maheshwari A, Bengtson P, Rousk J (2016) Comparative toxicities of salts on microbial processes in soil. Appl Environ Microbiol 82(7):2012-2020. https://doi. org/10.1128/AEM.04052-15

Redman RS, Sheehan KB, Stout RG et al (2002) Thermotolerance generated by plant/fungal symbiosis. Science 298(5598): 1581. https://doi.org/10.1126/science.1072191

Redman R, Henson J, Rodriguez R (2005) Symbiotic lifestyle expression by fungal endophytes and the adaptation of plants to stress. pp 683-695. https://doi.org/10.1201 /9781420027891

Rodriguez RJ, Redman RS, Henson JM (2004) The Role of Fungal Symbioses in the Adaptation of Plants to High Stress Environments. Mitig Adapt Strateg Glob Chang 9: 261. https://doi.org/10.1023/B:MITI.0000029922.31110.97

Rodriguez RJ, Henson J, Van Volkenburgh E et al (2008) Stress tolerance in plants via habitat-adapted symbiosis. ISME J 2: 404-416. https://doi.org/10.1038/ismej.2007.106

Saikkonen K, Young CA, Helander M, Schardl CL (2016) Endophytic Epichloë species and their grass hosts: from evolution to applications. Plant Mol Biol 90:665-675. https://doi.org/10.1007/s11103-015-0399-6
Saitou N, Nei M (1987) The neighbor-joining method: a new method for reconstructing phylogenetic trees. Mol Biol Evol 4:406-425. https://doi.org/10.1093/oxfordjournals. molbev.a040454

Schardl CL, Leuchtmann A, Spiering MJ (2004) Symbioses of grasses with seedborne fungal endophytes. Annu Rev Plant Biol 55:315-340. https://doi.org/10.1146/annurev. arplant.55.031903.141735

Selbmann L, De Hoog GS, Mazzaglia A et al (2005) Fungi at the edge of life: cryptoendolithic black fungi from Antarctic desert. Stud Mycol 51:1-32

Sena APA, Chaibub AA, Côrtes MVCB et al (2013) Increased enzymatic activity in rice leaf blast suppression by crude extract of Epicoccum sp. Trop Plant Pathol 38:387-397. https://doi.org/10.1590/S1982-56762013005000028

Shi Y, Lou K, Li C (2009) Promotion of plant growth by phytohormone-producing endophytic microbes of sugar beet. Biol Fertil Soils 65:645-653. https://doi.org/10.1007 /s00374-009-0376-9

Sieber TN (2007) Endophytic fungi in forest trees: are they mutualists? Fungal Biol Rev 21:75-89. https://doi.org/10.1016/j. fbr.2007.05.004

Singh K (2016) Microbial and enzyme activities of saline and sodic soils. Land Degrad Dev 27:706-718. https://doi. org/10.1002/ldr.2385

Smibert RM, Krieg NR (1994) Phenotypic characterization. In: Gerhardt P, Murray RGE, Wood WA, Krieg NR (eds) Methods for general and molecular bacteriology. American Society for Microbiology, Washington, DC, pp 607-654

Sonjak S, Udovič M, Wraber T et al (2009) Diversity of halophytes and identification of arbuscular mycorrhizal fungi colonising their roots in an abandoned and sustained part of Sečovlje salterns. Soil Biol Biochem 41:1847-1856. https://doi. org/10.1016/j.soilbio.2009.06.006

Strzelczyk E, Szpotański T (1989) Cellulolytic and pectolytic activity of Streptomycetes isolated from root-free soil, rhizosphere and mycorrhizosphere of pine (Pinus sylvestris L.). Biol Ferility Soils 7:365-369

Sun X, Guo L-D, Hyde KD (2011a) Community composition of endophytic fungi in Acer truncatum and their role in decomposition. Fungal Divers 47:85-95. https://doi.org/10.1007 /s13225-010-0086-5

Sun Y, Wang Q, Lu X et al (2011b) Endophytic fungi associated with two Suaeda species growing in alkaline soil in China. Mycosphere 2:239-248

Suryanarayan TS, Kumaresan V (2000) Endophytic fungi of some halophytes from an estuarine mangrove forest. Mycol Res $104: 1465-1467$. https://doi.org/10.1017 /S0953756200002859

Suzuki S, He Y, Oyaizu H (2003) Indole-3-acetic acid production in Pseudomonas fluorescens HP72 and its association with suppression of creeping bentgrass brown patch. Curr Microbiol 47:138-143. https://doi.org/10.1007/s00284-0023968-2

Szymańska S, Piernik A, Baum C et al (2014) Metabolic profiles of microorganisms associated with the halophyte Salicornia europaea in soils with different levels of salinity. Ecoscience 21:114-122. https://doi.org/10.2980/21-2-3705

Szymańska S, Płociniczak T, Piotrowska-Seget Z, Hrynkiewicz K (2016) Endophytic and rhizosphere bacteria associated with the roots of the halophyte Salicornia europaea L. - 
community structure and metabolic potential. Microbiol Res 192:37-51. https://doi.org/10.1016/j.micres.2016.05.012

Tamura K, Stecher G, Peterson D et al (2013) MEGA6: molecular evolutionary genetics analysis version 6.0. Mol Biol Evol 30: 2725-2729. https://doi.org/10.1093/molbev/mst197

Thomas P, Swarna GK, Roy PK, Patil P (2008) Identification of culturable and originally non-culturable endophytic bacteria isolated from shoot tip cultures of banana cv. Grand Naine. Plant Cell Tissue Organ Cult 93:55-63. https://doi. org/10.1007/s11240-008-9341-9

Thomma BPHJ (2003) Alternaria spp.: from general saprophyte to specific parasite. Mol Plant Pathol 4:225-236. https://doi. org/10.1046/j.1364-3703.2003.00173.x

Thongkantha S, Lumyong S, Mckenzie EHC, Hyde KD (2008) Fungal saprobes and pathogens occurring on tissues of Dracaena lourieri and Pandanus spp. in Thailand. Fungal Divers 30:149-169

Tian P, Nan Z, Li C, Spangenberg G (2008) Effect of the endophyte Neotyphodium lolii on susceptibility and host physiological response of perennial ryegrass to fungal pathogens. Eur J Plant Pathol 122:593-602. https://doi.org/10.1007 /s10658-008-9329-7

U'Ren JM, Lutzoni F, Miadlikowska J et al (2012) Host and geographic structure of endophytic and endolichenic fungi at a continental scale. Am J Bot 99:898-914. https://doi. org/10.3732/ajb.1100459

Ushakova SA, Kovaleva NP, Gribovskaya IV et al (2005) Effect of $\mathrm{NaCl}$ concentration on productivity and mineral composition of Salicornia europaea as a potential crop for utilization $\mathrm{NaCl}$ in LSS. Adv Sp Res 36:1349-1353. https://doi. org/10.1016/J.ASR.2004.09.017

Valdés-Santiago L, Ruiz-Herrera J (2014) Stress and polyamine metabolism in fungi. Front Chem 1:42. https://doi. org/10.3389/fchem.2013.00042

Vieira MLA, Hughes AFS, Gil VB et al (2012) Diversity and antimicrobial activities of the fungal endophyte community associated with the traditional Brazilian medicinal plant Solanum cernuum Vell. (Solanaceae). Can J Microbiol 58: 54-66. https://doi.org/10.1139/w11-105

Viterbo A, Ramot O, Chernin L, Chet I (2002) Significance of lytic enzymes from Trichoderma spp. in the biocontrol of fungal plant pathogens. Antonie Van Leeuwenhoek 81:549-556. https://doi.org/10.1023/A:1020553421740

Waller F, Achatz B, Baltruschat H et al (2005) The endophytic fungus Piriformospora indica reprograms barley to saltstress tolerance, disease resistance, and higher yield. Proc Natl Acad Sci 102:13386-13391. https://doi.org/10.1073 /pnas.0504423102

Waqas M, Khan AL, Kamran M et al (2012) Endophytic fungi produce gibberellins and indoleacetic acid and promotes host-plant growth during stress. Molecules 17:1075410773. https://doi.org/10.3390/molecules170910754

White RH, Engelke MC, Morton SJ et al (1992) Acremonium endophyte effects on tall fescue drought tolerance. Crop Sci 32:1392. https://doi.org/10.2135/cropsci1992.0011183 X003200060017x

Wilkins PW (1991) Breeding perennial ryegrass for agriculture. Euphytica 52:201-214. https://doi.org/10.1007/BF00029397

Wilkinson HH, Siegel MR, Blankenship JD et al (2000) Contribution of fungal loline alkaloids to protection from aphids in a grass-endophyte mutualism. Mol Plant-Microbe Interact 13:1027-1033. https://doi.org/10.1094 /MPMI.2000.13.10.1027

Yarullina LG, Akhatova AR, Kasimova RI (2016) Hydrolytic enzymes and their proteinaceous inhibitors in regulation of plant-pathogen interactions. Russ J Plant Physiol 63:193203. https://doi.org/10.1134/S1021443716020151

You Y, Lee M, Kim J (2014) Endophytic fungal diversity isolated from the root of halophytes in taean peninsula. Korean $\mathrm{J}$ Mycol 42:269-275. https://doi.org/10.4489 /KJM.2014.42.4.269

Young-Hyun Y, Hyeokjun Y, Sang-Mo K et al (2012) Fungal diversity and plant growth promotion of endophytic fungi from six halophytes in Suncheon Bay. J Microbiol Biotechnol 22:1549-1556. https://doi.org/10.4014 /jmb.1205.05010

Yuan Z, Druzhinina IS, Labbé J et al (2016) Specialized microbiome of a halophyte and its role in helping non-host plants to withstand salinity. Sci Rep 6:1-13. https://doi. org/10.1038/srep32467

Zhang J, Jia W, Yang J, Ismail AM (2006) Role of ABA in integrating plant responses to drought and salt stresses. F Crop Res 97:111-119. https://doi.org/10.1016/j. fcr.2005.08.018

Zhang D, Spadaro D, Valente S et al (2012) Cloning, characterization, expression and antifungal activity of an alkaline serine protease of Aureobasidium pullulans PL5 involved in the biological control of postharvest pathogens. Int J Food Microbiol 153:453-464. https://doi.org/10.1016/J. IJFOODMICRO.2011.12.016

Zhao S, Zhou N, Zhao ZY et al (2016) Isolation of endophytic plant growth-promoting bacteria associated with the halophyte Salicornia europaea and evaluation of their promoting activity under salt stress. Curr Microbiol 73:574-581. https://doi.org/10.1007/s00284-016-1096-7

Publisher's note Springer Nature remains neutral with regard to jurisdictional claims in published maps and institutional affiliations. 